Introduction to Special Issue of Women's History Review titled Representing,

Remembering and Rewriting Women's Histories of the First World War, forthcoming 2018

\title{
Introduction: Representing, Remembering and Rewriting Women's Histories of the First World War
}

\author{
Maggie Andrews, Alison Fell, Lucy Noakes and June Purvis
}

As Dan Todman has persuasively argued, in the British popular imagination the First World War is associated with mud, barbed wire, the trenches and the Tommy on the Western Front. ${ }^{1}$ Perhaps inevitably, therefore, public commemoration of the war has often been dominated by a focus on the men in the armed forces, who risked or lost their lives for causes that at the time may or may not have seemed heroic, noble or simply unavoidable. The visual spectacle of Paul Cummins' 'Blood Swept Lands and Seas of Red', the art installation at the Tower of London in which 888,246 ceramic poppies filled the moat from 17 July to 11 November 2014, was the most visited artistic response to the war in its centenary years, while Jeremy Deller's 'We're Here Because We're Here', commemorating the first day of the Battle of the Somme, provided a widely seen and moving memorial to the victims. ${ }^{2}$ This vision of the conflict, focusing exclusively on the combatant dead, should not, however, become the only history of the conflict. There are, as the research brought together here demonstrates, multiple histories of the First World War.

Where women have been included in centenary commemorations, certain women feature more than others. This selectivity in the representation of women occurred during the First World War itself, and since the conflict has been reproduced in museums and by heritage sites. It has provided a lexicon of images, impressions, roles and portrayals of women which still tend to shape the histories of women and the conflict. The Imperial War Museum's project Lives of the First World War, for example, has pulled together the life 
stories of over 8 million men and women from across Britain and the Commonwealth who served in uniform and worked on the Home Front during the First World War. However, its narrow definition of service as paid work outside the home has re-enforced the tendency to reproduce iconic images of nurses, munitionettes or landgirls.

The articles in this Special Issue are drawn from papers presented at the Women, Gender and the First World War: Home Fronts and War Fronts conference held at the University of Portsmouth in October $2015 .^{3}$ The articles are by both established and newly emerging scholars, but all build upon the work of a number of historians who, in recent years have resisted any simplistic framing of the debates about women and war. They do not, then, stake a claim for women's importance in the histories of the war by presenting them as heroic 'female Tommies', or by seeing war as an agent of positive change for women's position in society, a perspective articulated by Arthur Marwick over fifty years ago. ${ }^{4}$ Rather, the articles presented here are in the tradition of historians such as Susan Grayzel, ${ }^{5}$ Christine Hallett, ${ }^{6}$ Deborah Thom, ${ }^{7}$ Joanna Bourke, ${ }^{8}$ Susan Pedersen, ${ }^{9}$ Karen Hunt, ${ }^{10}$ Susan Kingsley Kent, ${ }^{11}$ Nicoletta Gullace ${ }^{12}$ and Janet Watson ${ }^{13}$, who have sought to stretch, challenge, expand and rework histories of the First World War. Building on this historiography, they place women's histories and questions about gender more centrally in our understanding of the conflict. Gender, class, age, and the social, cultural and economic specificity of the different localities in which British women lived, shaped the impact of the First World War on their lives. The articles in this Special Issue demonstrate that women's involvements in this first industrialized, mechanized total war was experienced, represented and remembered in the minutiae of practices, cultural interactions and emotions of their everyday lives in families or communities. Thus their choice of mourning dress, the music they listened to, the moral panics around their behaviour and the magazines in which they were portrayed are revealed to be an important part of the history of the First World War, complementing the history of soldiers on the battlefield. 
The critical approach of Jonathan Rayner's article 'The Carer, the Combatant and the Clandestine', exploring the representation of women in War Illustrated magazine, is a welcome contribution to contemporary scholarship. He draws our attention to how central images of female civilians in Europe were to British narratives of German atrocities. Further, he illuminates the complex representation of female nurses, who were portrayed both as vulnerable carers and potential victims whilst paradoxically as active heroines, involved in activities that could be viewed as transgressive in gender terms. Sarah Pedersen's article 'Suffragettes and the Scottish Press during the First World War' also focuses on the representation of women during the conflict in print media. In doing so it unpicks the myth that all suffragettes suspended lobbying and campaigning in order to support the war effort and explores some of their more complex and varied responses. The continuing lobbying of the British section of the Women's International League (WIL) for the franchise discussed in Sarah Hellawell's article 'Antimilitarism, Citizenship and Motherhood: the formation and early years of the Women's International League, 1915-1919' re-enforces this point.

Hellawell's article also reveals the extent to which the First World War amplified the growing pre-occupation of social welfare and medical reformers with motherhood. ${ }^{14}$ She explains how the WIL drew upon social and cultural experiences of motherhood both to challenge and to build bridges between women of enemy nations and to add weight to women's demands for citizenship. Alternatively, Catherine Lee's "Giddy Girls', 'Scandalous Statements' and a 'Burst Bubble': The war babies panic of 1914-15' interrogates the moral panic around the babies that it was alleged were likely to be born to unmarried young women and girls in the months that followed men's 'rush to the colours' and subsequent departure to the Western Front in the early months of the war. By demonstrating that it was particularly young working class women who were believed to be vulnerable to 'khaki fever', Lee shows how existing beliefs and prejudices could be refocused by wartime conditions. Practices of everyday life and the cultural production of the era also significantly or 
subtly evolved as the influence and impact of the war rippled out into music, theatre, and fashion. Ideas of appropriate emotional responses, displays of feelings and intimate actions could be stretched and reimagined. Lucie Whitmore, in her article 'A Matter of Individual Opinion and Feeling' addresses the changes that took place within the culture of mourning dress between 1914 and 1918. She considers how attitudes towards death and the rituals associated with bereavement were altered by the conflict. The numbers of younger war widows, for example, changed what was considered appropriate dress, and women's magazines bear witness to the extent to which women's mourning practices were shifting in response to the hundreds of thousands of war deaths. Laura Seddon, in 'Gendered Musical Responses to First World war Experiences' investigates how women composers responded to the First World War in 1915 and 1916. She suggests that this music, largely neglected by critics and historians, contributes to a re-evaluation of how women composers experienced the cultural impacts of the war.

Who is remembered and how they are remembered, whether at a national level or at an individual, family or community level, is the result of a complex interplay of different forces. Lucy Noakes's article "My husband is interested in war generally" explores the emotional legacies of total war, drawing on a 2014 Mass Observation Directive which asked its panelists to reflect on their feelings about the war. Many of them, men and women, focused on the ways the war had negatively impacted on their families, leaving women widowed, children fatherless and returning men physically and mentally scarred. She points out that older women often had a personal memory of the lived legacies, and felt a responsibility to pass on the 'lessons' of war to a younger generation who, they feared, had little or no sense of the horrors of warfare Finally, Amanda Phipps also addresses questions around contemporary memories of the war in her article 'What the Women Did: remembering or reducing women of the First World War on the contemporary British stage'. Here, she considers a trio of wartime plays revived by Two's Company at the Southwark 
Playhouse in 2014. Unlike many recent productions that focused on the soldier's story, these theatrical performances brought a wider range of women's stories to life by revealing their failings, suffering and ambivalence towards men. However, the fact that they were lowbudget and small-scale also demonstrates the competitive and commodified nature of remembrance that dictates which stories are kept alive in the twenty-first century.

The articles published here are only a small sample of the papers discussed at the conference but they have been chosen to reflect something of the diversity of topics that were explored. There are of course many omissions from a publication that focuses upon only one country, and within Britain there are many geographical areas which have been omitted. The aim is not to offer a complete or necessarily a representative portrayal of contemporary scholarship on British women's relationship with the First World War, but to make a contribution to what is an ongoing and evolving process of rewriting British women's histories of the conflict. We hope the material here will stimulate debate, discussion and further scholarship.

${ }^{1}$ Dan Todman (2005) The Great War: myth and memory (London: Bloomsbury).

2 'We're here because we're here' marked the centenary of the first day of the Battle of the Somme. Hundreds of volunteers, working with the artist Jeremy Deller, Birmingham Repertory Theatre, the National Theatre and 1914-18 Now, commemorated the centenary by re-enacting as soldiers in cities, towns and the countryside around Britain. First World War soldiers were seen at train stations, shopping centres, beaches, car parks and high streets.. For further details see: https://becausewearehere.co.uk/

${ }^{3}$ The conference was organised by June Purvis with financial support from Women's History Network Southern, the Centre for European and Internationl Studies Research Centre (CEISR) at the University of Portsmouth, and the AHC funded Gateways to the First World War public engagement centre, based at the University of Kent.

${ }^{4}$ Arthur Marwick (1968) Britain in the Century of Total War: War, Peace, and Social Change, 19001967 (London: Little, Brown) and his 1991 book The deluge: British society and the first world war (Houndmills: Macmillan). 
${ }^{5}$ Susan R. Grayzel (1999) Women's Identities at War. Gender, Motherhood, and Politics in Britain and France during the First World War (Chapel Hill: University of North Carolina Press).

${ }^{6}$ Christine E. Hallett (2009) Containing trauma: nursing work in the First World War (Manchester: Manchester University Press).

${ }^{7}$ Deborah Thom (1998) Nice Girls and Rude Girls: Women Workers in World War 1 (London: I B Tauris).

${ }^{8}$ Joanna Bourke (1996) Dismembering the Male: men's bodies, Britain, and the Great War (Chicago: University of Chicago Press).

${ }^{9}$ Susan Pedersen (1995) Family, dependence, and the origins of the welfare state: Britain and France, 1914-1945 (Cambridge: Cambridge University Press).

${ }^{10}$ Karen Hunt (2010) The politics of food and women's neighborhood activism in First World War Britain, International Labor and Working-Class History 77 (1), pp. 8-26.

${ }^{11}$ Susan Kingsley Kent (1988), The politics of sexual difference: World War I and the demise of British feminism, The Journal of British Studies 27 (3), pp. 232-253.

${ }^{12}$ Nicoletta Gullace, The Blood of Our Sons: Men, Women and the Renegotiation of British citizenship during the Great War (Basingstoke: Palgrave, 2002).

${ }^{13}$ Janet Watson, Fighting Different Wars: Experience, Memory and the First World War in Britain (Cambridge University Press, 2004)

14 Grayzel, Women's Identities at War; Anna Davin (1978) Imperialism and motherhood, History Workshop Journal, April, pp. 9-65. 